\title{
Development in broaching technology Part I. Development of broaching machines and tooling devices
}

\author{
Postęp w obróbce przeciąganiem \\ Część I. Rozwój przeciągarek i oprzyrządowania narzędziowego
}

The paper structured into three parts outlines the present state of the broaching technology. The first part highlights possible process variants for internal and external operations and designs of broaching machines as well as CNC control systems and other advanced automatization forms. The second part will be devoted to the progressive broaching methods such as rotary broaching, hard broaching and MQL application. The third part will discuss some important directions of experimental investigations carrying out for more efficient and reliable broaching processes.

KEYWORDS: broaching technology, broaching machines, broaching tools

W artykule przedstawiono aktualny stan obróbki przeciąganiem z podziałem na trzy części. W pierwszej części omówiono odmiany procesu i konstrukcje obrabiarek za szczególnym uwzględnieniem napędu ruchu głównego, sterowania CNC i zaawansowanych form automatyzacji. W drugiej części zostanie przeprowadzony przegląd sposobów przeciągania, takich jak przeciąganie obrotowe, materiałów utwardzonych i obróbki MQL. Trzecia część będzie poświęcona ważnym kierunkom prowadzonych badań doświadczalnych procesu przeciągania.

SŁOWA KLUCZOWE: przeciąganie, przeciągarki, przeciągacze

\section{Wprowadzenie}

Przeciąganie należy do sposobów obróbki skrawaniem, w których zasadniczo jako narzędzie kształtowe stosuje się przeciągacz o budowie jednolitej lub składanej oraz zespoły przeciągaczy. Naddatek obróbkowy jest usuwany kolejno przez pojedyncze ostrza lub grupę ostrzy o podobnej geometrii, w trybie warstwa po warstwie, ze stałą prędkością [1-3]. Wśród sposobów skrawania przeciąganie wyróżnia się tym, że:

- przeciągarki mają prostą konstrukcję, ponieważ zwykle występuje jeden prostoliniowy ruch główny, a ruch posuwowy jest zastąpiony przez zmianę wymiaru ostrzy,
- ze względu na małą prędkość skrawania $(2,5 \div 12$ $\mathrm{m} / \mathrm{min}$ ) oraz niewielką grubość warstwy skrawanej $(5 \div 15 \mu \mathrm{m}$ dla ostrzy wykończeniowych) uzyskuje się dużą dokładność (zwykle IT7) i dobrą jakość powierzchni $(R a=0,8 \div 2,5 \mu \mathrm{m})$; najczęściej stosuje się napęd hydrauliczny, dlatego ruch narzędzia jest bardzo stabilny, a w przypadku małej prędkości skrawania nie tworzy się narost,

- przeciąganie jest procesem bardzo wydajnym ze względu na stosowanie specjalnych narzędzi wieloostrzowych; w skrawaniu uczestniczy równocześnie wiele ostrzy narzędzia i czynna długość krawędzi skrawających jest duża; w jednym cyklu pracy narzędzia przeprowadza się zabieg zgrubny, półwykończeniowy i wykończeniowy, a nawet kalibrowanie przez pierścienie nagniatające,

- narzędzie jest trwałe z uwagi na małą prędkość skrawania; ostrza mogą być wielokrotnie przeszlifowane, co wydłuża żywotność narzędzia i obniża koszty obróbki.

Na rys. 1 przedstawiono różne profile przedmiotów wykonywanych przez przeciąganie oraz cechy geometryczne narzędzi, którymi się je uzyskuje. Do podstawowych odmian przeciągania zalicza się obróbkę otworów (powierzchni wewnętrznych) i powierzchni zewnętrznych. W pierwszym przypadku

\footnotetext{
* Prof. dr hab. inż. Wit Grzesik, w.grzesik@po.edu.pl, https://orcid.org/0000-0003-3898-5119 - Katedra Technologii Maszyn i Automatyzacji Produkcji Politechniki Opolskiej, Opole, Polska
} 
obrabia się otwory cylindryczne, kwadratowe, wieloboczne (poligonalne), wielorowkowe (typu spline) o różnych kształtach i stożkowe. Do prowadzenia narzędzia potrzebny jest otwór wstępny. W drugim przypadku można kształtować rozmaite powierzchnie, w tym: płaskie, kształtowe, wklęsłe i wypukłe, powierzchnie zębów kół zębatych, części chwytowe łopatek turbin i rowki jodełkowe w tarczach turbin.

Według znanego producenta przeciągarek - firmy American Broach and Machine Company [5] - w zależności od konstrukcji maszyn wyróżnia się następujące odmiany przeciągania:

1. Przeciąganie głowicą (pot broaching), w którym przeciągacze do powierzchni zewnętrznych są rozmieszczone promieniowo. W ten sposób kształtuje się zęby kół zębatych lub inne profile usytuowane na obwodzie przedmiotu. Przedmiot jest przemieszczany do góry. Uzyskuje się dużą wydajność i dobrą jakość powierzchni.

2. Przeciąganie poziome (horizontal broaching), w którym narzędzie jest ciągnione w kierunku poziomym przez fragment powierzchni przedmiotu zamocowanego w uchwycie lub w specjalnej oprawce. W ten sposób obrabia się rowki wpustowe i szczeliny (prześwity), ale także otwory wielorowkowe z większymi tolerancjami.

3. Przeciąganie pionowe $\mathrm{z}$ ruchem stołu do góry (vertical table up broaching). Część jest mocowana w uchwycie na platformie w kształcie ramy, która przemieszcza ją do góry względem nieruchomego narzędzia. Zaletą tego sposobu jest korzystne dla operatora usytuowanie miejsca załadunku i wyeliminowanie podwyższenia czy specjalnej platformy do jego transportu

4. Przeciąganie pionowe $\mathrm{z}$ ruchem narzędzia do dołu (vertical pull-down broaching). Przedmiot jest zamocowany w uchwycie, a narzędzie jest ciągnione w dół przez otwór wstępny w celu kształtowania zarysu wewnętrznego. Taki układ obróbkowy jest bardzo sztywny, co umożliwia uzyskanie zarysów o dużej dokładności wymiarowo-kształtowej i wysokiej jakości powierzchni. Wadą jest natomiast usytuowanie stołu roboczego wysoko nad podłogą.

5. Pionowe przeciąganie powierzchni (vertical surface broaching) - część jest mocowana w uchwycie, a zespół płaskich przeciągaczy usytuowanych w ramowym prowadniku wcina się w powierzchnię zewnętrzną. Taki proces stosuje się do obróbki powierzchni płaskich i kształtowych, m.in. wypustów lub rowków jodełkowych w wirnikach turbin.

6. Przeciąganie pionowe $z$ ruchem narzędzia do dołu i dwoma cylindrami hydraulicznymi lub aktuatorami liniowymi (twin-cylinder pull-down broaching) jako odmiana wariantu nr 4. Cylindry są mocowane do stołu i w czasie pracy wysuwane w kierunku przestrzeni roboczej. Tłoki są przytwierdzone do prowadnika, co powoduje, że kierunek siły ciągnienia narzędzia pokrywa się dokładnie z osią narzędzia i eliminuje efekt ugięcia. Uchwyt ciągadła jest również prowadzony w stojaku, co dodatkowo poprawia dokładność obróbki.
7. Przeciąganie pionowe z głowicą przytwierdzoną do stołu obrabiarki (table top broaching). Jest to kolejna modyfikacja wariantu $\mathrm{nr}$ 5, tzw. TT model, w którym zamiast ramowego prowadnika zastosowano dwie śruby toczne, po każdej stronie osi przeciągacza, przesuwające uchwyty. Przeciągarki pracujące według tej zasady mają kompaktową budowę i zajmują niewielką przestrzeń roboczą.

Inny podział uwzględnia następujące typy przeciągarek stosowanych w przemyśle: poziome, pionowe przeciągarki (typu pull-up) i przepycharki (typu pull-down), do przeciągania ciągłego, ze stołem obrotowym, do kształtowych powierzchni zewnętrznych, do rowków wpustowych. Przykłady konstrukcji przeciągaczy o różnych zastosowaniach w wielu odmianach kinematycznych procesu przedstawiono na rys. 2.

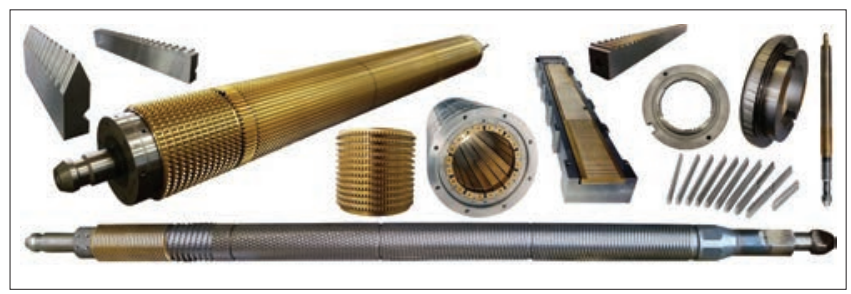

Fig. 2. Examples of broaching tools with various designs and applications (www.varinelli.com)

Rys. 2. Przykłady przeciągaczy o różnych konstrukcjach i zastosowaniach (www.varinelli.com)

\section{Przegląd konstrukcji przeciągarek}

Przeciągarki poziome mają mocną konstrukcję i są przystosowane do szerokiego zakresu zarysów przedmiotów, obejmującego m.in.: wewnętrzne zarysy ewolwentowe, wewnętrzne zarysy SAE, bruzdy w lufach, elementy prowadzące (prowadniki), otwory cylindryczne, kwadratowe i sześciokątne, rowki wpustowe i klinowe, wewnętrzne kształty typu D oraz wewnętrzne otwory wielokarbowe. Na rys. 3 przedstawiono nowoczesną przeciągarkę CNC o masie $10 \mathrm{t}$ i skoku 120 cali (ok. $3000 \mathrm{~mm}$ ), wyposażoną w napęd mechaniczny za pomocą śruby tocznej, oraz typowy asortyment części obrabianych przez przeciąganie.

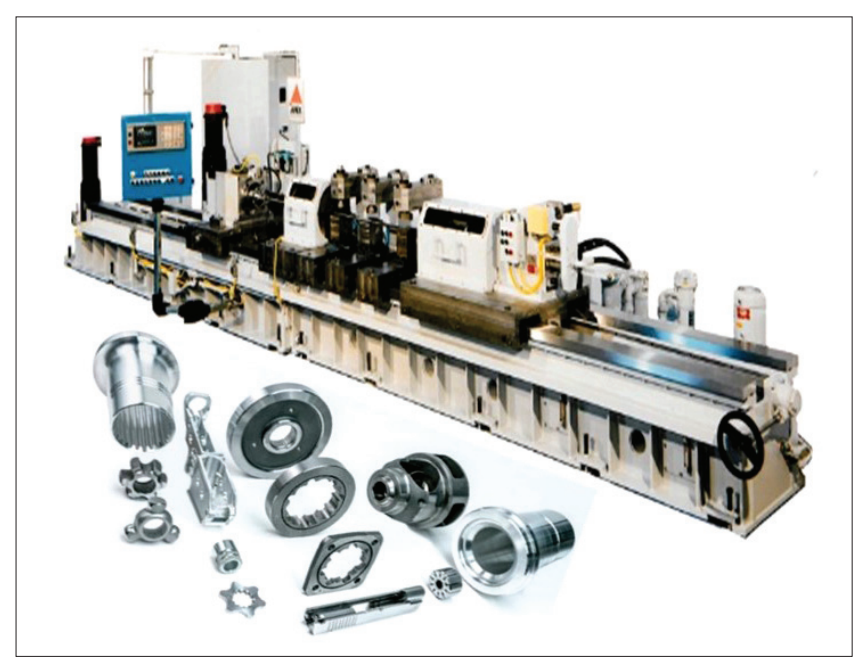

Fig. 3. A modern horizontal CNC broaching machine and an assortment of machined parts (www.apbsi.com/broaching-machines) Rys. 3. Nowoczesna pozioma przeciągarka CNC i asortyment obrabianych przedmiotów (www.apbsi.com/broaching-machines) 
Przeciągarki pionowe są przystosowane do wykonywania przedmiotów o różnych zarysach, podobnie jak przeciągarki poziome. Ich podstawowym zastosowaniem jest jednak obróbka otworów z powtarzającymi się zarysami. Na rys. 4 przedstawiono nowoczesną pionową przeciągarkę CNC typu table-up wyposażoną w napęd hydrauliczny (rys. $4 a$ ) oraz typowy asortyment części z zarysami wielorowkowymi, obrabianymi przez przeciąganie głowicami (typu pot broaching) (rys. 4b).

$\mathrm{Na}$ rys. 5 widać pionową przeciągarkę CNC typu table up $\mathrm{z}$ podwójnym napędem elektromechanicznym (rys. 5a) i model napędu elektrycznego (rys. 5c). Konstrukcja układu nośnego typu $\mathrm{H}$ z podwójną śrubą
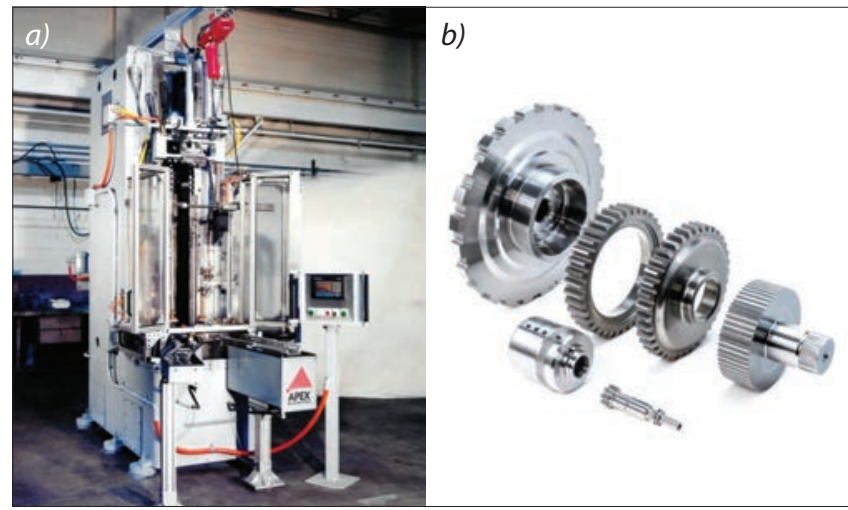

Fig. 4. Modern vertical table-up CNC broaching machine $(a)$ and variety of machined parts with external splines with a repeating outline (b) (www.apbsi.com/broaching-machines)

Rys. 4. Nowoczesna pionowa przeciągarka CNC typu table-up (a) i asortyment obrabianych przedmiotów z zewnętrznymi powierzchniami o powtarzającym się zarysie (b) (www.apbsi.com/broaching-machines)

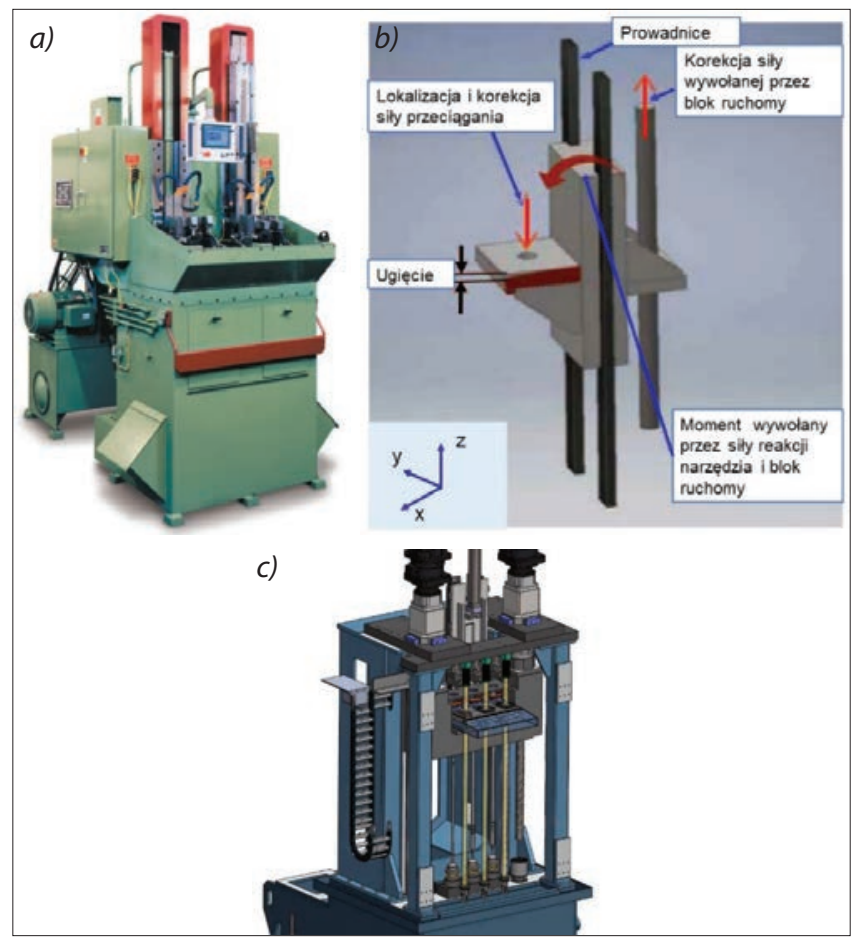

Fig. 5. Modern vertical table up broaching machine with double elec tric drive (a) (www.ohiobroach.com) and the mechanical loading of the working system $(b)$ [6], vertical broaching machine model with double electric drive (c) (www. broachingmachine.com)

Rys. 5. Nowoczesna pionowa przeciągarka typu table up z podwójnym napędem elektrycznym (a) (www.ohiobroach.com) i układ obciążenia układu obróbkowego (b) [6], model przeciągarki pionowej z podwójnym napędem elektrycznym (c) (www.broachingmachine.com) (rys. 5b) charakteryzuje się zwiększoną sztywnością i stabilnością w porównaniu z napędem za pomocą jednej śruby $[6,11]$. Powodem tego jest wyeliminowanie ugięcia stołu roboczego pod wpływem momentu siły przeciągania. Występują wtedy błędy geometryczne spowodowane biciem powierzchni stołu, głównie nieprostopadłość otworu. W konstrukcji typu H oś przedmiotu jest usytuowana dokładnie w środku między dwoma głównymi elementami ruchomymi, a kierunki składowych siły przeciągania są równoległe do osi przedmiotu. W ten sposób bicie czołowe w przeciąganiu części helikopterów zredukowano z 0,005" $\div 0,006^{\prime \prime}$

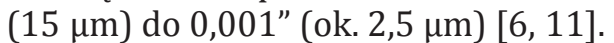
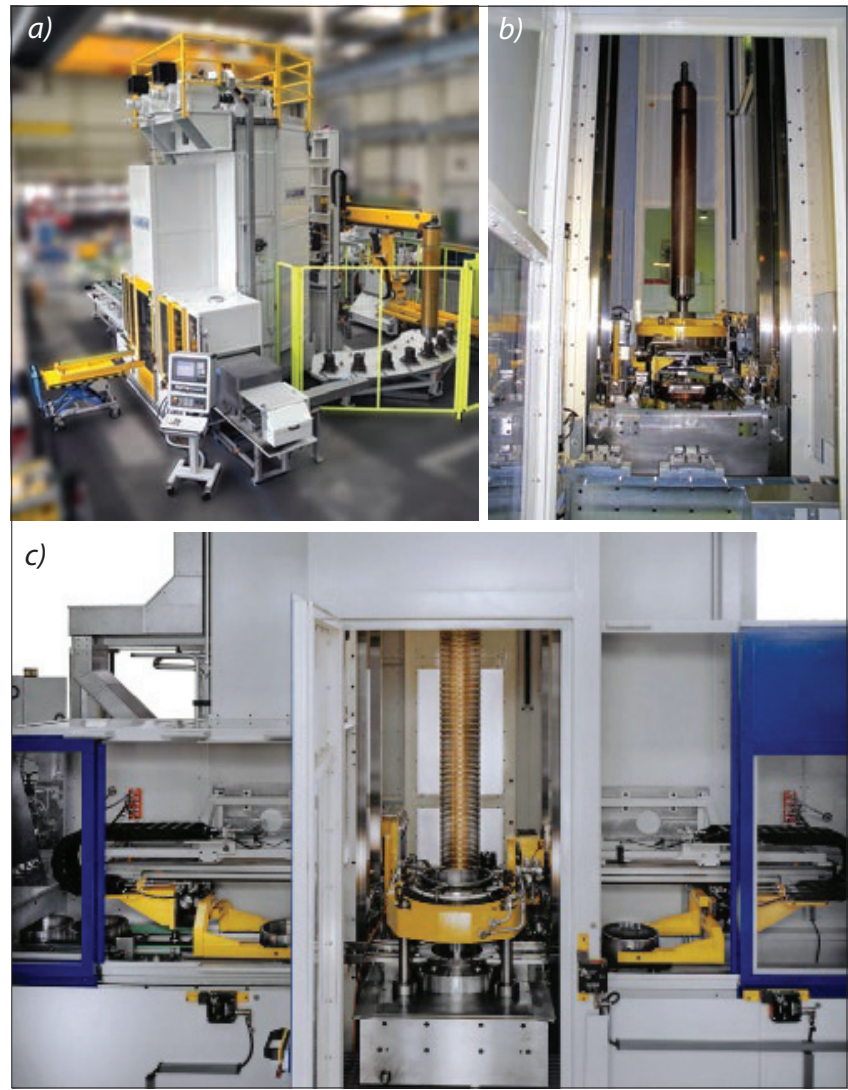

Fig. 6. Modern CNC vertical table up screw broaching machine with full automatic tool change $(a)$, view of the working space $(b)$ and loading of broaching parts (c) (www.varinelli.com)

Rys. 6. Nowoczesna pionowa przeciągarka śrubowa CNC typu table up z w pełni automatyczną wymianą narzędzia (a) oraz widok przestrzeni roboczej (b) i załadunku przedmiotów (c) (www.varinelli.com)

Na rys. 6 przedstawiono pionową przeciągarkę śrubową CNC typu table up $\mathrm{z}$ automatyczną wymianą narzędzia (rys. 6a) i napędem elektromechanicznym (rys. 6b). W czasie gdy przedmiot jest mocowany osiowo na stole głównym, przeciągacz wykonuje ruch obrotowy. Kąt pochylenia linii śrubowej rowka jest nastawiany elektronicznie odpowiednio do zmierzonego kąta pochylenia linii śrubowej ostrzy przeciągacza.

Na rys. $7 a$ pokazano nowe rozwiązanie prowadnika narzędzia w układzie podwójnym. Zastosowano również oszczędne smarowanie zamiast tradycyjnego obfitego chłodzenia/smarowania. Natomiast na rys. $7 b$ zaprezentowano zasadę pracy przeciągarko-przepycharki (pull-push type), w której końcówki chwytowe narzędzia są dokładnie mocowane 


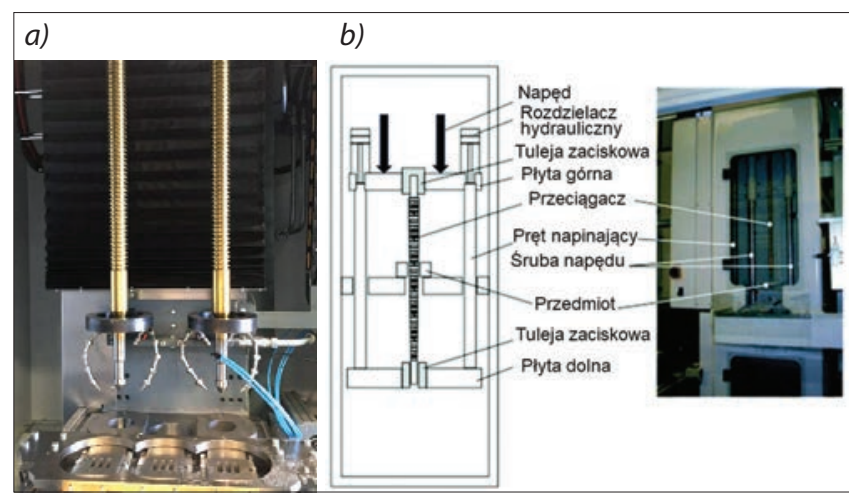

Fig. 7. New solution of the tool guide in a vertical table up broaching machine (a) (www.colonialtool.com) and a pull-push broaching machine (b) [2]

Rys. 7. Nowe rozwiązanie prowadnika narzędzia w pionowej przeciągarce typu table up (a) (www.colonialtool.com) oraz przeciągarka typu pull-push (b) [2]

w tulejach zaciskowych w płycie górnej i dolnej. Obydwie płyty i stół roboczy są ze sobą sprzężone za pomocą prętów napinających układ, połączonych z tłokami cylindrów hydraulicznych. Cały sztywny układ jest przemieszczany równomiernie w czasie obróbki za pomocą śrub tocznych. W rezultacie eliminowane są drgania powstające w czasie wcinania się ostrzy, gdy dominuje rozciąganie, oraz efekt wyboczenia w drugiej fazie obróbki, gdy narzędzie pracuje jako przepychacz.

Specjalną grupę przeciągarek pionowych stanowią obrabiarki przystosowane do nacinania zewnętrznych i wewnętrznych zarysów wielorowkowych (typu rotating table blind spline broaching) na pewnej długości, ograniczonej zwykle kołnierzem. Na rys. 8 przedstawiono pionową przeciągarkę ze stołem obrotowym typu rotating table broach, przystosowaną do obróbki ślepych zarysów wielorowkowych na walcowych powierzchniach zewnętrznych (rys. 8a), oraz przykładowe części z wykonanymi zarysami wielorowkowymi (rys. 8b).

Zasadniczo przeciągarki tego typu mają stół obrotowy podziałowy lub o ruchu liniowym, na którym montuje się zespoły przeciągaczy. Część lub partie części są automatycznie ładowane na trzpienie przez chwytak (chwytaki) z pionowym ramieniem wysięgnikowym. Następnie są przemieszane w szybkim cyklu do

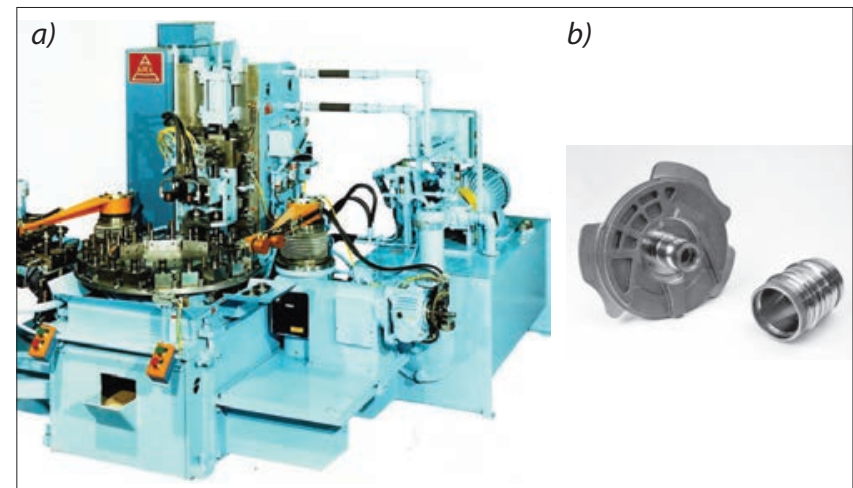

Fig. 8. Vertical broaching machine with a rotating table for blind spline broaching $(a)$ and examples of machined parts with external blind splines (b) (www.apbsi.com)

Rys. 8. Pionowa przeciągarka ze stołem obrotowym typu rotating table blind spline broaching (a) oraz przykłady obrabianych przedmiotów (b) (www.apbsi.com) kontaktu z narzędziem, a po zakończeniu obróbki stół przemieszcza się i automatycznie usuwa części. Możliwa jest równoczesna, bardzo wydajna obróbka ślepych zarysów wewnętrznych i zewnętrznych zamiast klasycznego nacinania metodą kształtową lub obwiedniowa.

Do obrabiarek specjalnych zalicza się pionowe (rys. 9) i poziome przeciągarki do rowków w sprężarkach i wirnikach turbin. Stosuje się specjalne przeciągacze do rowków na jaskółczy ogon (dovetail type broach) i jodełkowych (fir/Christmas tree broach) - jak pokazano na rys. 10.

W wirnikach sprężarek silników odrzutowych rowki służące do mocowania łopatek mają kształt jaskółczego ogona i są przeciągane narzędziem o takim samym kształcie (rys.10). Natomiast przeciągacze o kształcie jodełkowym stosuje się do wykonywania rowków, w których osadza się łopatki w wirnikach turbiny. Należy tu podkreślić, że jodełkowy kształt rowka jest podyktowany gwarancją bardzo korzystnego rozkładu naprężeń $\mathrm{w}$ atmosferze o wysokim ciśnieniu i temperaturze. Spełnia też rygorystyczne
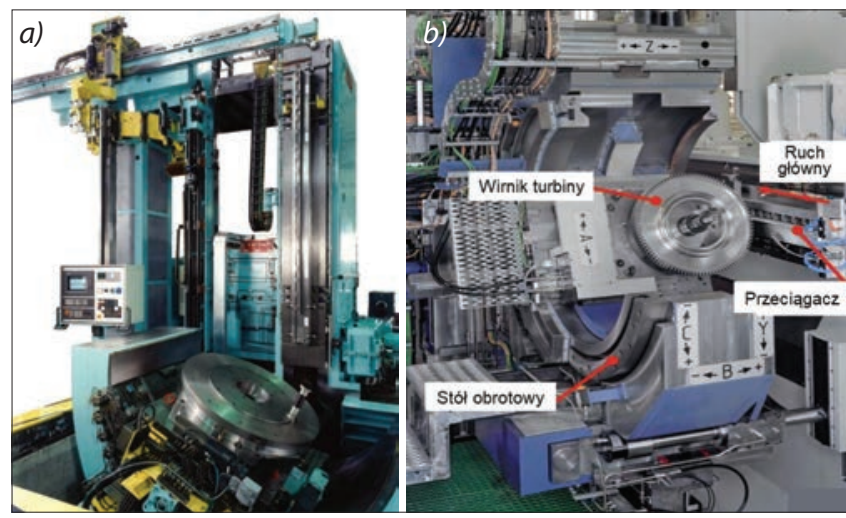

Fig. 9. Vertical broaching machine for machining grooves in turbine discs (a) (www.varinelli.com) and the designation of the controlled axes (b) [7]

Rys. 9. Pionowa przeciaggarka do obróbki rowków w wirnikach turbin (a) (www.varinelli.com) i oznaczenia osi sterowanych (b) [7]

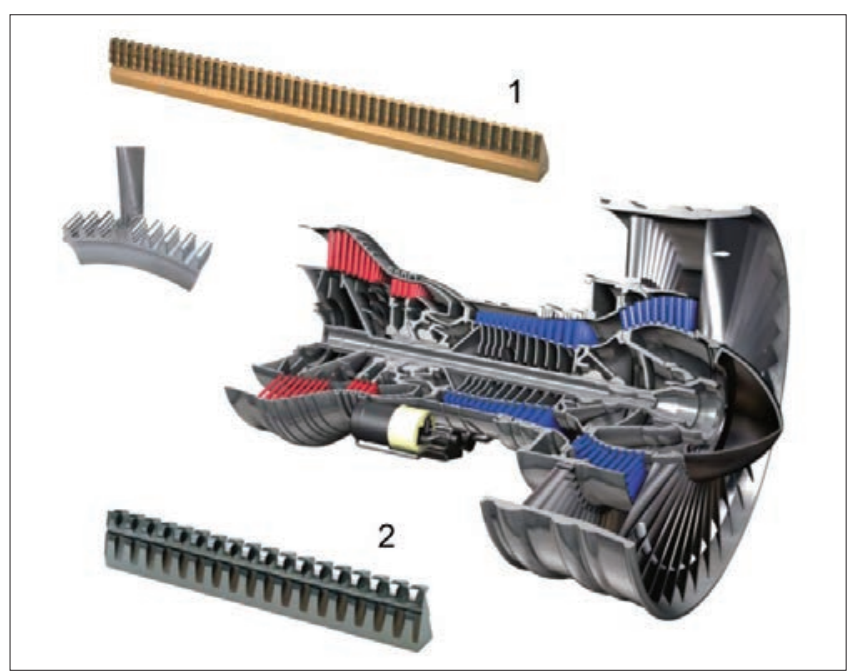

Fig. 10. Schematic diagram of grooving in discs of compressors and aircraft turbines: 1 - broach for fir/Christmas tree grooves, 2 - broach for dovetail type grooves (www.nachiamerica.com)

Rys. 10. Schemat poglądowy obróbki rowków w wirnikach sprężarek i turbin lotniczych: 1 - przeciągacz do rowków jodełkowych, 2 przeciągacz do rowków na jaskółczy ogon (www.nachiamerica.com) 
wymagania nie tylko co do dokładności kształtu, lecz także jakości powierzchni oraz zmian charakterystyk warstwy wierzchniej w czasie pracy turbiny, w tym jej plastyczności (w warunkach pełzania wysokotemperaturowego). Szczegółowe informacje o cechach konstrukcyjnych przeciągaczy do rowków jodełkowych i zasadach podziału naddatku obróbkowego zostaną omówione w drugiej części artykułu.

\section{Zastosowanie zaawansowanej automatyzacji i sterowania CNC w przeciąganiu}

Rozwój automatyzacji i sterowania jest w przypadku przeciągarek związany z ogólną tendencją do łączenia wielu funkcji w jednej obrabiarce. Chociaż przeciąganie należy do najszybszych sposobów obróbki, to w latach 2005-2010 - czyli okresie intensywnego rozwoju sterowania CNC, oprogramowania CAD/CAM i serwonapędów - rozwiązania te nie były właściwie wprowadzane w przeciągarkach [7]. Nasuwa się pytanie, czy w XXI w. przeciąganie będzie ujęte w takich strategiach, jak inteligentne wytwarzanie (Smart Manufacturing, Internet Rzeczy - IoT czy Przemysł 4.1 - Industry 4.1).

W przeciągarkach stosuje się raczej sterowanie PLC niż CNC, co nie przeszkadza w ich włączeniu do sieci zarządzania produkcją. Problem polega na tym, że w przypadku przeciagania sterowana jest tylko jedna oś liniowa i niemożliwe jest pełne wykorzystanie sterowania wieloosiowego oraz zaawansowanego oprogramowania. W zasadzie wystarczą G-kody stosowane w operacjach wiercenia. Natomiast wspomniane działania mogą być rozwijane zwłaszcza $\mathrm{w}$ razie zastosowania przeciągania do kształtowania uzębień, ponieważ jego znaczenie $\mathrm{w}$ tym obszarze nadal pozostaje istotne. Przewiduje się nawet wzrost udziału przeciągania w produkcji pojazdów z napędem elektrycznym. Uważa się $[8,10]$, że podstawowy kierunek rozwoju dotyczy zastosowania przeciągarek z napędem elektromechanicznym w produkcji części o małych i średnich wymiarach oraz gdy pojawiają się problemy z użyciem oleju jako środka smarującego. Przeciągarki z napędem hydraulicznym nadal będą dominować w obróbce części o dużych wymiarach. Podstawową korzyścią jest prawie całkowite wyeliminowanie kształtowego nacinania zębów śrubowych w przemyśle samochodowym.

Trzy zasadnicze zastosowania napędów elektromechanicznych to podnoszenie stołu w przeciągarkach pionowych typu table up broach (rys. 11), napęd w przeciągarkach z głowicą typu top broach oraz napęd ruchu głównego w przeciągarkach poziomych. W przypadku przeciągarki pionowej przedstawionej na rys. 11 uzyskuje się siłę do $60 \mathrm{~T}$ w produkcji pierścieni zębatych $\mathrm{z}$ wewnętrznym uzębieniem śrubowym i prostoliniowym. Ważnym zagadnieniem w projektowaniu przeciągarek jest wyeliminowanie ugięć i przemieszczeń w czasie skoku roboczego.

W rozwiązaniu konstrukcyjnym przeciągarki przedstawionym na rys. $11 \mathrm{w}$ celu zwiększenia wydajności produkcji można użyć dwóch przeciągaczy i uchwytów przedmiotu. Wtedy czas cyklu obróbkowego

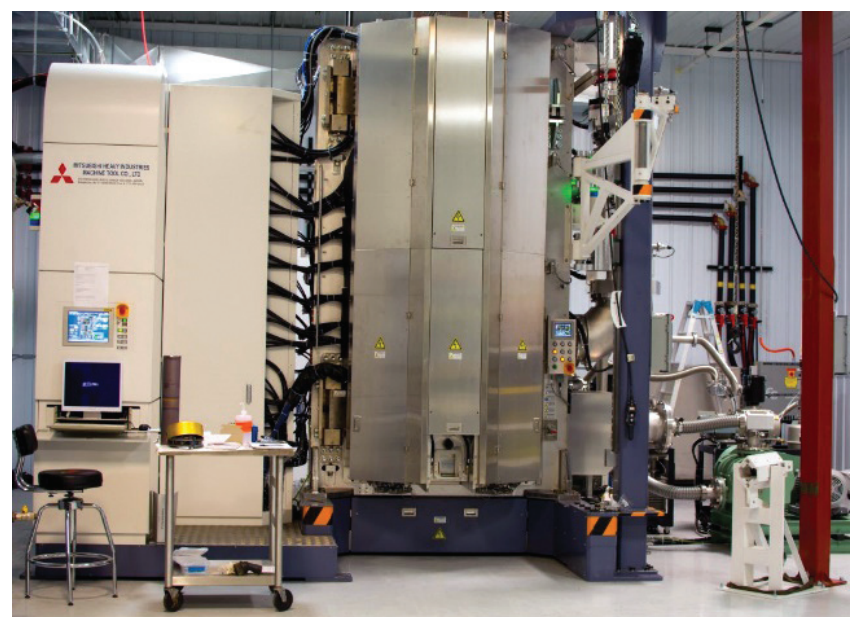

Fig. 11. Vertical broaching machine with electromechanically powered lifting mechanisms of the working table [8] (www.gearsolution. com)

Rys. 11. Przeciągarka pionowa z elektromechanicznym mechanizmem podnoszenia stołu [8] (www. gearsolution.com)

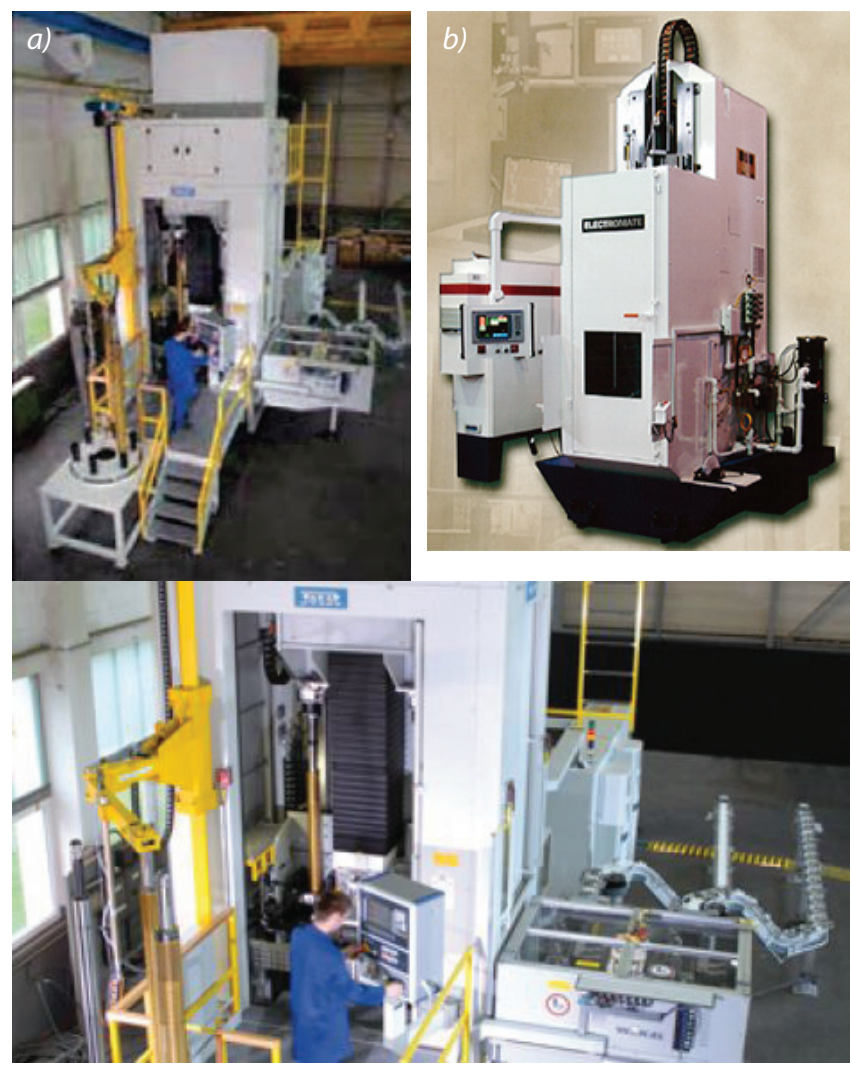

Fig. 12. Examples of vertical broaching machines equipped with advanced control and automation systems [6]: a) www.forst-online. com, b) www.broachingmachine.com [9]

Rys. 12. Przykłady przeciągarek pionowych z zaawansowanymi środkami sterowania i automatyzacji [6]: a) www.forst-online.com, b) www.broachingmachine.com [9]

skraca się z 22 s do 11 s. Dodatkowo stosuje się specjalne podajniki z mechanizmami planetarnymi.

Stosowane obecnie środki zaawansowanej automatyzacji i sterowania przedstawiono na rys. 12 . Na rys. $12 a$ widać dwustacyjną przeciaggarkę pionową do zarysów śrubowych wyposażoną w układ sterowania CNC oraz manipulatory do podawania i przemieszania przedmiotów. Sterowanie CNC osią obrotu narzędzia podczas skoku roboczego generuje dokładne pochylenie linii śrubowej. Możliwe są chwilowe nastawienie i zmiana linii śrubowej bez dodatkowych urządzeń 
mechanicznych. W przeciągarce pionowej pokazanej na rys. $12 b$ zastosowano napędy elektromechaniczne, serwonapędy i bardzo dokładne śruby toczne lub planetarne mechanizmy toczne.

W przypadku zautomatyzowanych systemów obróbki oprzyrządowanie technologiczne spełnia kilka ważnych funkcji, m.in.:

- lokalizuje dokładnie część na obrabiarce,

- ustawia i/lub mocuje część w odpowiedniej pozycji wobec narzędzia,

- zapewnia właściwy kierunek ruchu przeciagacza,

- zabezpiecza przedmiot i narzędzie przed uszkodzeniem,

- ułatwia uzyskanie najwyższej wydajności procesu.

Korzystne parametry technologiczne przeciągarek pionowych $\mathrm{z}$ podnoszonym stołem (typu table up) i fakt, że nie potrzeba przy nich dodatkowej platformy dla operatora, stwarzają możliwość ich integracji w stacji obróbkowej (rys. 13a) obsługiwanej przez robota (rys. 13b) i z zastosowaniem innych urządzeń manipulacyjnych [9].

Na rys. 14 umieszczono wirtualny model całkowicie zautomatyzowanej stacji obróbki wirników turbin. Tak wysoki poziom automatyzacji procesu przeciągania to standard w Produkcji 4.0, który jest obecnie przedmiotem prac rozwojowych prowadzonych przez czołowych producentów przeciągarek.

W części II opracowania zostaną omówione aktualne osiągnięcia w zakresie nowych metod przeciągania, w tym tzw. przeciąganie obrotowe (rotacyjne) umoż-

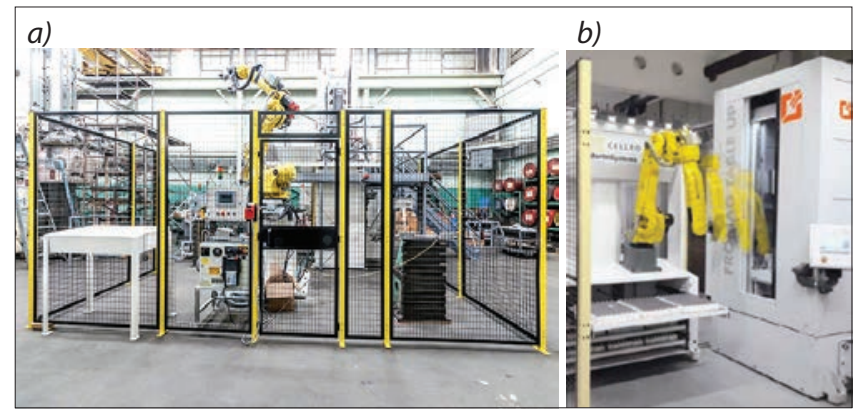

Fig. 13. Fully automatic broaching cell $(a)$ and application of a robot to part handling $(b)[6,9]$ (www.apbsi.com)

Rys. 13. Całkowicie zautomatyzowana stacja przeciaggania (a) i obsługa przeciągarki przez robota w zrobotyzowanej stacji obróbkowej (b) $[6,9]$ (www.apbsi.com)

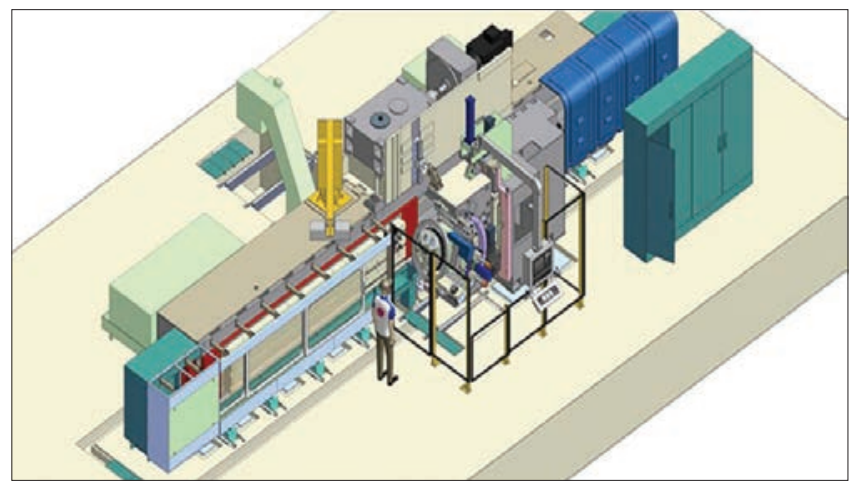

Fig. 14. Virtual model of a fully automatic turbine discs broaching cell (www.fivesgroup.com)

Rys. 14. Wirtualny model całkowicie zautomatyzowanej stacji do przeciagania wirników turbin (www.fivesgroup.com) liwiające przeprowadzenie operacji przeciągania na centrach tokarskich i frezarskich, materiałów utwardzonych (na twardo) i z zastosowaniem minimalnego chłodzenia.

\section{LITERATURA}

[1] Olszak W. „Obróbka skrawaniem”. Warszawa: PWN, 2017.

[2] Toenshoff H.K., Denkena B. "Basic of Cutting and Abrasive Processes". Heidelberg: Springer, 2013.

[3] Grzesik W. „Podstawy skrawania materiałów konstrukcyjnych". Warszawa: PWN, 2018

[4] Arrazola J.P., Rech J., M'Saoubi R., Axinte D. „Broaching: Cutting tools and machine tools for manufacturing high quality features in components". CIRP Annals Manufacturing Technology. 69/2 (2020): 554-577, https://doi.org/10.1016/j.cirp.2020.05.010.

[5] McGuinn J. "Broaching in the $21^{\text {st }}$ Century". Gear Technology. May (2018): 26-30, www. geartechnology.com.

[6] Stott W.R. "State-of-the-art broaching". Gear Technology. August (2011): 62-66, www. geartechnology.com.

[7] Schulze V. "Broaching". "CIRP Encyclopaedia of Production Engineering", 2014 Edition, doi: https://doi org/10.1007/978-3-642-20617-7_6686.

[8] Desrochers C., Bryant K. "An update on broaching technology". Gear Solution Magazine. March (2016), www. gearsolution.com.

[9] Cannella A. "The latest in broaching". Gear technology. January/February (2020): 29-31, www. geartechnology.com.

[10] Adams L. "Technology advances CNC broaching systems". 2019, www.ctemag.com.

[11] Egrin M. "Advantages of a dual-screw $\mathrm{H}$-frame broaching machine". Gear Solutions. March (2019): 37-39, www. gearsolutions.com. 